\title{
P203 CHEMICAL FLOODING - A TECHNOLOGICAL. \\ ECONOMICAL AND EFFECTIVE METHOD FOR ENHANCED \\ OIL RECOVERY IN CHINA
}

DAKUANG HAN, CHENGZHI YANG

PUHUA YANG and YUHUAI QIAN

Research Institute of Petroleum Exploration and Development,

PO Box 910, Beijing 100083, China

\section{Introduction}

Most of the oil fields in China are discovered in Continental Sedimentary basins with fluvial-delta and alluvial fan-fan delta sedimentary systems. The diversified sedimentary systems resulted in a large variation in petrophysical property of reservoirs : Clastic rocks are the main reservoir rock type, with its high content of muddy or calcium cement over $5 \%$, some reaching $15 \sim 20 \%$; Pay zones are of distinct multicycle structures, showing a rather heterogeneous feature with multi-rhythmite structure and a high value of variant coefficien of permeability (Dykstra-Parsons) of over 0.6 , some reaching $0.8 \sim 0.9$. Frequent tectonic movements complicated the reservoir structures and created various fault block reservoirs and resulted in the accumulation of crude oil with high viscocity. While developed by water injection technique, these oil fields, therefore are observed a fast increase of water cut and a low oil recovery. Considering the average oil recovery of only 33 . $16 \%$ (OOIP) reported based on prediction, lab. test and dense well spacing test, the over $80 \%$ water cut and the current recoverg of merely 20\% (OOIP) in most of the developed oil fields of China. We should espect a great potential in enhancing oil recoverv

China has all long attached great importance to the research and application of the oil recovery technique. The characteristics of petroleum geolgoy and the physical property of fluid in oil fields of China all suggest that chemical flooding are applicable for most of the developed oil fields of the country. Through lab. study and pilot test, we have gradually solved the problems regarding to the field application of polymer flooding, surfactant flooding, surfactant-alkali-polymer combination flooding (SAP or ASP) and alkali-polymer flooding, conducted demonstration test and commerical application of these techniques. The result indicates that the oil reocvery can increase about $10 \%$ (OOIP) by polymer flooding and about 15 20\% (OOIP) by surfactant-alkali-polymer combination flooding. Chemical flooding technique therefore is a technological and economical effective method for EOR in most of the developed oil fields of China.

\section{Favourable terms for applying chemical flooding in develped oil fields of China.}

2. 1 Screening parameters for chemical flooding in oil feilds.

Based on the geological background and the current status of the chemical flooding in China and the experiences of some oil producing countries such as USA, we recommend the following parameters employing chemical flooding in oil fields of China(Table 1): 
Table. 1 Recommended screening parameters for chemical flooding

\begin{tabular}{|c|c|c|c|c|c|}
\hline & Parameter & $\begin{array}{l}\text { Caustic } \\
\text { flooding }\end{array}$ & $\begin{array}{l}\text { Polymer } \\
\text { flocding }\end{array}$ & $\begin{array}{l}\text { Surfactant } \\
\text { flooding }\end{array}$ & $\begin{array}{l}\text { Combination } \\
\text { flooding }\end{array}$ \\
\hline & viscosity, $\mathrm{mPa} \cdot \mathrm{s}$ & $\cdot<40$ & $<60$ & $<40$ & $<60$ \\
\hline $\begin{array}{l}\text { Crud oil } \\
\text { property }\end{array}$ & $\therefore$ specific gravity & $<0.9$ & $<0.9$ & $<0.9$ & $<0.9$ \\
\hline & acid value, $\mathrm{mgKOH} / \mathrm{g}$ & $>0.2$ & 1 & 1 & $>0.2$ \\
\hline Formtion & salinity, $\mathrm{mg} / \mathrm{l}$ & $<10000$ & $<10000^{\circ}$ & $<10000$ & $<10000$ \\
\hline water & hardness, mg/l & $<100$ & $<500^{\circ}$ & $<500$ & $<500$ \\
\hline & depth,m & $<2500$ & $<2500$ & $<2500$ & $<2500$ \\
\hline & temperature, ${ }^{\mathrm{C}}$ & $<90$ & $<75$ & $<80$ & $<75$ \\
\hline Reservoir & effective thicness, $\mathrm{m}$ & / & 1 & $/$ & / \\
\hline & $\begin{array}{l}\text { effective permeabiltiy, } \\
\qquad 10^{-3} \mu \mathrm{m}^{2}\end{array}$ & $>50$ & $>50$ & $>50$ & $>50$ \\
\hline & lithology & sandstone & sandstone & sandstone & \\
\hline Orhers & favoruable factors & $\begin{array}{l}\text { high acide } \\
\text { value }\end{array}$ & $\begin{array}{l}\text { low tempera- } \\
\text { ture, fresh } \\
\text { water, het- } \\
\text { erogeneous }\end{array}$ & $\begin{array}{l}\text { low clay con- } \\
\text { tent, low } \\
\text { hardness wa- } \\
\text { ter }\end{array}$ & $\begin{array}{l}\text { low tempera- } \\
\text { ture, fresh } \\
\text { water, high } \\
\text { acide vaiue, } \\
\text { heteroge- } \\
\text { neous }\end{array}$ \\
\hline 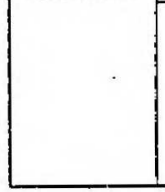 & unfavourable factors & $\begin{array}{l}\text { high content } \\
\text { of clay, gyp- } \\
\text { sum and cal- } \\
\text { carious min- } \\
\text { erals }\end{array}$ & $\begin{array}{l}\text { bottom wa- } \\
\text { ter, high con- } \\
\text { tent of calcar- } \\
\text { ious minerals }\end{array}$ & $\begin{array}{l}\text { fracture, bot- } \\
\text { tome water, } \\
\text { heteroge- } \\
\text { neous }\end{array}$ & $\begin{array}{l}\text { gas cap, bot- } \\
\text { tom water }\end{array}$ \\
\hline
\end{tabular}

* No these restriction for Xanthan Gum flooding

2. 2 Favourable Terms for chemical flooding in oil fields of China.

(1) The crude oil features high content of wax and high viscosity. The crude oil with viscosity at $3 \sim 50 \mathrm{mPa} . \mathrm{s}$ accounts for $70 \%$ of the crude in the country. To increase the viscocity of displacing water is therefore favourable to the improvement of creasment of sweeping efficiency. The low salinity of formation water makes it easier to select chemical agent.

(2) In some oil fields of Bohai Gulf area, the crude oil features high content of acid, making a favourable condition for the in-situ forming of surfactant.

(3) In eastern China area, most of the developed oil fields feature shallow buried depth and moderate reservoir temperature, providing a favourable environment for keeping the thermal stability of oil displacing agent.

(4) The strong heterogereity of reservoirs, espercially the positive rhythm reservoirs polycyclidy deposited are favourable to improved injection water profile by polymer flooding.

(5) In the developed oil fields of eastern China, high effective permeability of most of 
the reservoirs, it will not the refore create a large reducton of injectablility while empolying polymer flooding and chemical combination flooding in these areas.

(6) The reservoirs are mostly sandstones in which generaly no fractures developed and hence the injected chemical agent generaly will not chonnelling along fractures.

3. Technical and economical success of chemical flooding in oil fields of China.

3. 1 Development and commercicalization of chemical oil displacement agent

Diversified chemical agents used for chemical flooding such as polyarylamide (PAM), Xanthan Gum, surfactant and alkali, etc have been already studied for many years and by now the production techniques of these chemicals have been well mastered and the chemicals have been put into commercial production (Table 2).

Tabhle. 2 Production capacity of Chemical oil displacing agent in China

\begin{tabular}{|c|c|}
\hline Product & Productivity $(\mathrm{t} / \mathrm{y})$ \\
\hline Polyarylamide & $\sim 60000$ \\
\hline Xanthan Gum & $\sim 5000$ \\
\hline Surfactant (Specially for oil displacement) & $\sim 10000$ \\
\hline Caustic (commonly use) & conventional product \\
\hline
\end{tabular}

3. 2 In-depth understanding on mechanism and techniques of polymer flooding

The study on the property of the polymer solution and its flowing in porus medium proves that the mechanism of the polymer flooding is to increase sweep efficiency by improving water-oil mobility ratio and to improve volume sweep efficeincy through increasing residual resistance coefficient.

The well-designed surface mixing-injection station, transportation process and well completion helps to have kept a maximum viscocity value of the polymer solution from injection station to proder.

Restricting the salinity, hardness and oxgen content in injection water helps to have a stable polymer solution. The solution of Xanthan Gum is more stable than that of polyarylamite.

The molecular weight and its distribution of polymer selected must be coordinative with permeability porosity and pore throat radius of oil beoring formation.

The amount of polymer injected is delermined based on a comprehensive consideration on increasment of oil recovery, benefit of polymer and integrating economic benefit (Fig. 1). In Daqing oil field, $11 \%$ OOIP oil recovery increasment is obtained, with a polymer injection rate of $490 \mathrm{mg} / \mathrm{l}$. pv. The injection rate of polymer varies with oil property and geological conditions in different oil fields.

Pilot test of polymer flooding are conducted with different process in various oil fields as shown in Table 3 , technical success have been obtained in all of these pilot tests. In Yumen and Shengli oil fields, ecouraging results are also obtained from Xanthan Gum flouding pilot test (Table 4.) 
Table. 3 Pilot test data from polymer flooding

\begin{tabular}{|c|c|c|c|c|c|c|c|c|}
\hline Project & $\begin{array}{l}\text { Well } \\
\text { patern }\end{array}$ & $\begin{array}{c}\text { Number of } \\
\text { injection } \\
\text { wells }\end{array}$ & $\begin{array}{c}\text { Number of } \\
\text { producing } \\
\text { wells }\end{array}$ & $\begin{array}{c}\text { well } \\
\text { spacing } \\
\text { m }\end{array}$ & $\begin{array}{c}\text { Date of } \\
\text { test }\end{array}$ & $\begin{array}{l}\text { Injection } \\
\text { rate } \\
\mathrm{mg} / \mathrm{l} \cdot \mathrm{pv}\end{array}$ & $\begin{array}{c}\text { oil recovery } \\
\text { increase } \\
\% 001 P\end{array}$ & $\begin{array}{c}\text { benefit } \\
\text { of polymer } \\
t / t\end{array}$ \\
\hline Daqing - X1 & $\begin{array}{l}\text { anti-nine } \\
\text { points }\end{array}$ & 1 & 4 & 75 & $1972-73$ & 163 & 5.1 & 153.4 \\
\hline Daqing-HP & five points & 4 & 9 & 200 & $1988-90$ & 292 & 4. 3 & 81.8 \\
\hline Daqing OP & five points & 4 & 9 & 16 & $1990-92$ & 506 & 14 & 241 \\
\hline Daqing PT & five points & 4 & 9 & 106 & $1990-92$ & 496 & 11.6 & 209 \\
\hline Dagang G4K & irregular & 3 & 11 & $200-360$ & $1986-89$ & 123 & 12.7 & 445 \\
\hline $\begin{array}{c}\text { Shuanghe } \mathbb{I}_{5} \text {, } \\
\text { Henan }\end{array}$ & four points & 3 & 7 & $130--210$ & $1994-96$ & 199 & 9.8 & 181 \\
\hline
\end{tabular}

Table. 4 Pilot test data from bio-polymer flooding

\begin{tabular}{|c|c|c|c|c|c|c|c|c|}
\hline Project & $\begin{array}{c}\text { Well } \\
\text { patern }\end{array}$ & $\begin{array}{c}\text { Number of } \\
\text { injection } \\
\text { wells }\end{array}$ & $\begin{array}{c}\text { Number of } \\
\text { producing } \\
\text { wells }\end{array}$ & $\begin{array}{c}\text { well } \\
\text { spacing } \\
\mathrm{m}\end{array}$ & $\begin{array}{c}\text { Date of } \\
\text { test }\end{array}$ & $\begin{array}{c}\text { Injection } \\
\text { rate } \\
\mathrm{mg} / \mathrm{l} \cdot \mathrm{pv}\end{array}$ & $\begin{array}{c}\text { oil recovery } \\
\text { increase } \\
\% \text { OOIP }\end{array}$ & $\begin{array}{c}\text { benefit } \\
\text { of polymer } \\
\mathrm{t} / \mathrm{t}\end{array}$ \\
\hline $\begin{array}{c}\text { Shiyougou, } \\
\text { Yumen }\end{array}$ & irregular & 4 & 19 & 70 & $1992-93$ & 520 & $/$ & 229 \\
\hline $\begin{array}{c}\text { Gudong7, } \\
\text { Shengli }\end{array}$ & five poines & 4 & 9 & $\sim 150$ & $1994-$ & 600 & $/$ & $\begin{array}{c}\text { being in } \\
\text { process }\end{array}$ \\
\hline
\end{tabular}

The evaluation index and classification on polymer flooding of Dagang oil field is summerized in Table 5.

Table. 5 Evaluation index and classification of polymer flooding

\begin{tabular}{|c|c|c|c|c|c|c|c|}
\hline Tyep & $\begin{array}{c}\text { benefit } \\
\text { of polymer } \\
\text { t/t }\end{array}$ & $\begin{array}{c}\text { oil recovery } \\
\text { increase } \\
\%(\text { OOIP) }\end{array}$ & $\begin{array}{c}\text { Hell curve } \\
\text { slop ratio }\end{array}$ & $\begin{array}{c}\text { Swept volume } \\
\text { increase } \\
\text { ratio }\end{array}$ & $\begin{array}{c}\text { reduction of } \\
\text { water } \\
\text { production PV }\end{array}$ & $\begin{array}{c}\text { Displacement } \\
\text { curve } \\
\text { slope ratio }\end{array}$ & input/output \\
\hline I & $>400$ & $>10$ & $>2.5$ & $>0.2$ & $>1$ & $>1.4$ & $>4$ \\
\hline I & $201-399$ & $8-9.99$ & $2-2.5$ & $0.15-0.19$ & $0.8-0.99$ & $1.3-1.39$ & $3-3.9$ \\
\hline II & $100-199$ & $4-7.9$ & $1.5-2$ & $0.1-0.14$ & $0.4-0.79$ & $1.20-1.29$ & $2-2.7$ \\
\hline N & $<100$ & $<4$ & $<1.5$ & $<0.1$ & $<0.4$ & $1-1.19$ & $<1.9$ \\
\hline
\end{tabular}

Being currently in the demonstration test and commerical appication, and polymer flooding has become one of the technical measures to enhance oil recovery in oil fields of China. 
Table. 6 Demonstration test and commercial application of polymer flooding in oil fields of China

\begin{tabular}{|c|c|c|c|c|c|c|}
\hline Project & $\begin{array}{c}\text { area } \\
\mathrm{km}^{2}\end{array}$ & well pattern & $\begin{array}{c}\text { number of } \\
\text { injecrion wells }\end{array}$ & $\begin{array}{c}\text { Number of } \\
\text { producting wells }\end{array}$ & $\begin{array}{c}\text { well spacing } \\
\mathrm{m}\end{array}$ & $\begin{array}{c}\text { Date of } \\
\text { test }\end{array}$ \\
\hline Dagang G4K & 0.86 & irregular & 6 & 11 & $100-360$ & 1991.4 \\
\hline Daqing TP & 3.13 & $\begin{array}{c}\text { five pont } \\
\text { pattern }\end{array}$ & 21 & 36 & 250 & 1993 \\
\hline Daqing LP1 & 1.45 & $\begin{array}{c}\text { five pont } \\
\text { pattern }\end{array}$ & 16 & 25 & 212 & 1994 \\
\hline Daqing LP2 & 2.09 & $\begin{array}{c}\text { five pont } \\
\text { pattern }\end{array}$ & 9 & 26 & 300 & 1994 \\
\hline Daqing Beierxi & 14.25 & $\begin{array}{c}\text { five pont } \\
\text { pattern }\end{array}$ & 97 & 110 & 250 & 1995 \\
\hline Dagang G3E & 0.81 & irregular & 7 & 11 & $100-360$ & 1994 \\
\hline Dagang G3W & 1.30 & irregular & 7 & 18 & $100-360$ & 1991 \\
\hline Shengli GD2 & 4.08 & line patter & 40 & 78 & $300 \times 150$ & 1994 \\
\hline Shengli GD3 & 4.54 & line patter & 42 & 54 & $300 \times 150$ & 1994 \\
\hline
\end{tabular}

3. 3 Distinct improvement obtained in chemical combination flooding

Having integrated the advantages of surfactant flooding polymer flooding and caustic flooding, we have developed the alkali-surfactant-polymer (ASP) combination flooding technique and alkali-polymer (AP) combination flooding technique applying to acid crude, also the surfactant-alkali-polymer (SAP) comtination flooding technique applying to waxy curde. With high viscosity and high surfactivity, these oil displacement agents can improve oil-water mobility ratio. increase sweep effieiency, greatly reduce oil-water interfacial tension (Fig. 2) and increase oil displacement efficiency. In addition, the alkali in combination solution saponated with organic acid in oil crude, in-situ forming surfactant. The surfactant becomes more surfactivity due to the synergistic effect between in-situ forming surfactant and added surfactant. The alkali in combination solution can adjust also the arrangement of surfactant in oil-water interface so that the interficial tension can be reduced to the minimum value. The alkali in solution can also inbibate the loss of chemical agent caused by absorption and retation.

The concentration of surfactant in ASP (or SAP) systme developed is merely $1 / 10$ $1 / 25$ of that used in surfactant flooding but we have obtained same EOR increasment as that by surfactant flooding. The surfactant developed is compatible to both acide crude oil and waxy crud oil, forming supper-low interfacioal tension over a wide range of concentration of surfactan.

The field pilot test data of chemical combination flooding are listed in Table 7. This techniques can increase $14 \sim 20 \%$ (OOIP) of oil recovery. The benetif of the chemical agents is $150 \mathrm{t}$ of oil/t of surfactant. 
Table. 7 EOR pilot test data of chemical combination flooding

\begin{tabular}{|c|c|c|c|c|c|c|c|c|c|c|c|}
\hline \multirow[b]{2}{*}{ Project } & \multirow[b]{2}{*}{$\begin{array}{c}\text { well } \\
\text { pattern }\end{array}$} & \multirow{2}{*}{$\begin{array}{c}\text { Number of } \\
\text { injection } \\
\text { well }\end{array}$} & \multirow{2}{*}{$\begin{array}{c}\text { Number of } \\
\text { producer }\end{array}$} & \multirow{2}{*}{$\begin{array}{c}\text { well } \\
\text { spacing } \\
\text { m }\end{array}$} & \multicolumn{3}{|c|}{ formula ${ }^{\circ}, \%$} & \multicolumn{3}{|c|}{ in:ection rate, PV } & \multirow{2}{*}{$\begin{array}{c}\text { oii } \\
\text { recovery } \\
\text { increase } \\
\% \text { (OOIP) }\end{array}$} \\
\hline & & & & & $S$ & A & $\mathbf{P}$ & $\begin{array}{l}\text { pre- } \\
\text { slug }\end{array}$ & $\begin{array}{l}\text { main } \\
\text { slug }\end{array}$ & $\begin{array}{l}\text { post- } \\
\text { slug }\end{array}$ & \\
\hline $\begin{array}{l}\text { Shengli } \\
\text { GD4 }\end{array}$ & $\begin{array}{l}\text { five point } \\
\text { pattern }\end{array}$ & 4 & 9 & 50 & $\begin{array}{c}0.21 \\
0.2\end{array}$ & 1.5 & 0.1 & $\begin{array}{l}0.05 \\
0.05\end{array}$ & 0.35 & 0.1 & 13.4 \\
\hline $\begin{array}{c}\text { Daqing } \\
\text { SPO }\end{array}$ & $\begin{array}{l}\text { five point } \\
\text { pattern }\end{array}$ & 4 & 9 & 106 & 0.6 & 1. 25 & 0.12 & & 0.3 & 0.3 & 20.2 \\
\hline $\begin{array}{c}\text { Daqing } \\
\times 5\end{array}$ & $\begin{array}{l}\text { five point } \\
\text { pattern }\end{array}$ & 1 & 4 & 142 & 0.3 & 1.25 & 0.12 & & 0.3 & 0.3 & $\begin{array}{c}15.6 \\
\text { (now) } \\
21 \\
\text { (predicted) }\end{array}$ \\
\hline $\begin{array}{c}\text { Kelamayi } \\
2 \mathrm{ZH}\end{array}$ & $\begin{array}{c}\text { five point } \\
\text { pattern }\end{array}$ & 4 & 9 & $50^{\circ}$ & 0.3 & 1.4 & 0.18 & 0.32 & 0.3 & $\begin{array}{l}0.15 \\
0.15\end{array}$ & $\begin{array}{c}20 \\
\text { (predicted) }\end{array}$ \\
\hline $\begin{array}{l}\text { Liaohe } \\
\text { XLT }\end{array}$ & $\begin{array}{c}\text { four point } \\
\text { pattern }\end{array}$ & 3 & 5 & $\begin{array}{c}160 \\
\sim 180\end{array}$ & & 2 & 0.1 & . & 0.35 & & $\begin{array}{c}7.49 \\
\text { (predicted) }\end{array}$ \\
\hline
\end{tabular}

* S-sumertant, A-alkali, P-polymer

\section{Conclusion}

(1) There is a great potential for enhancing oil recovery in oil fields of China. Chemical flooding techniques such as polymer flooding and chemcial combination flooding are the approprate ones for most of these oil fields.

(2) Being both technically and econmiclly effective, polymer flooding has become a commercialized process and measure for EOR in some oil fields of China.

(3) Being able to increase $15 \sim 20 \%$ OOIP oil recovery, chemical combination flooding is an EOR technique with great prospects and will be very possibly to be commercialized.

\section{References}

1. Chengzhi, Yang and Dakuang, Han, Present Status of EOR in the Chinese Petroleum Industry and its Future, JPSE, 6 (1991) 175-189.

2. Chengzhi, Yang: China's EOR Response to Its Geological Characteristics, Petro$\min$, October, 1996, p52-62.
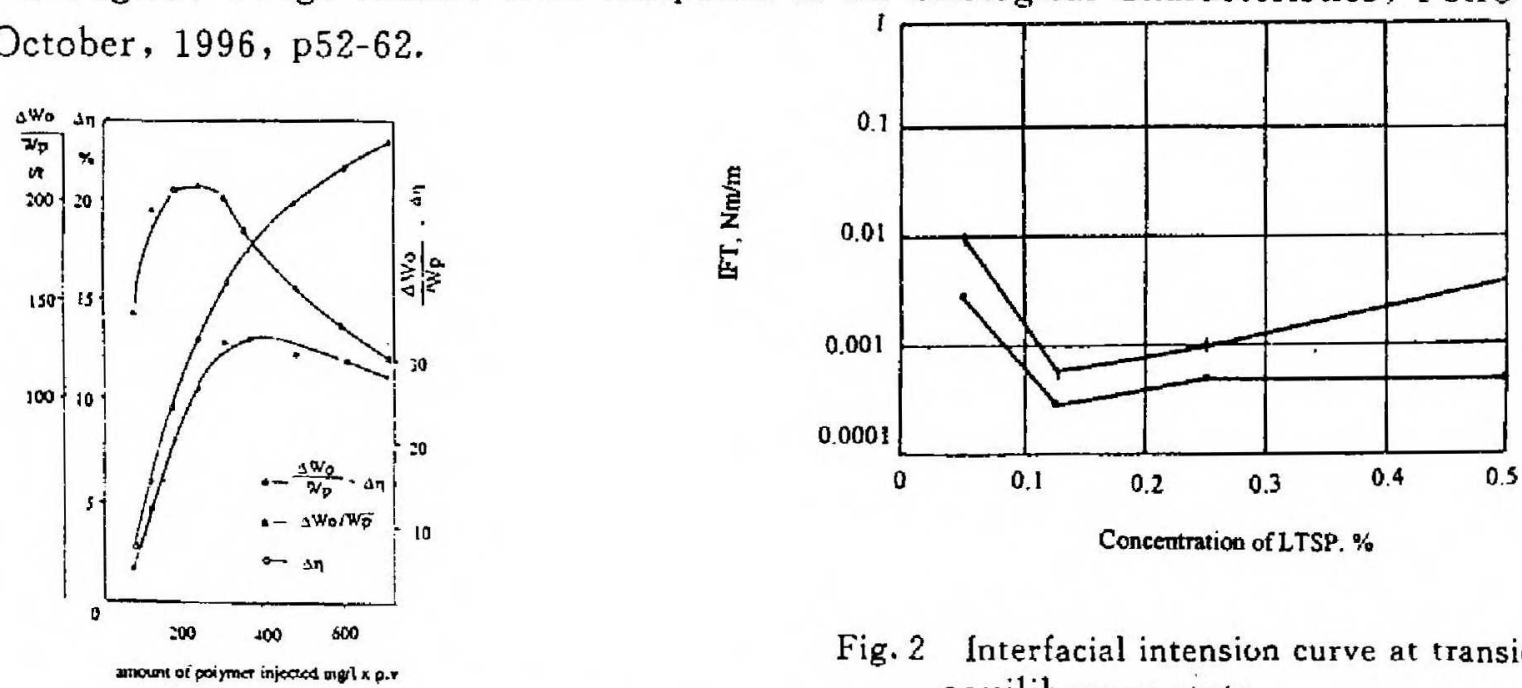

Fig. 2 Interfacial intension curve at transient an:t equilibraum state

Fig, 1 Relationship between polymer injection rate and oil recovery increasment and binifit of polymer 